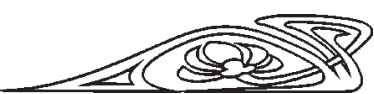

УДК821.161.1.09-3+929 Кржижановский \section{СИГИЗМУНДА КРЖИЖАНОВСКОГО}

МИР КАК “ДОЧКА ЗРЕНИЯ»: ОПЫТЫ “ОСТРАНЕНИЯ»

\section{Е. Г. Трубецкова}

Саратовский государственный университет

E-mail: etrubetskova@gmail.com

В статье рассматриваются особенности визуальной поэтики Сигизмунда Кржижановского. Прослеживается реализация в прозе писателя приема «остранения», описанного русскими формалистами.

Ключевые слова: С. Кржижановский, визуальная поэтика, «остранение», формализм.

The World As a "Girl/Child Point of View»: Sigizmund Krzhizhanovsky's Practices of «Estrangement»

\section{E. G. Trubetskova}

The features of visual poetics of Sigizmund Krzhizhanovsky are considered in the article. The technique of «estrangement» as described by the Russian formalists is traced in the writer's prose.

Key words: S. Krzhizhanovsky, visual poetics, «estrangement», formalism.

Описанный формалистами прием «остранения» - универсальный эстетический принцип, не случайно сам В. Шкловский показывал его реализацию на примере прозы Льва Толстого, а не в произведениях близкого ему русского авангарда 1 . В то же время и «остранение» В. Шкловского, и «новое зрение» Ю. Тынянова тесно связаны с контекстом эпохи. Увидеть мир по-новому - очищенным от привычного автоматизма восприятия взглядом - стало общей целью и одновременно предметом острых дискуссий представителей разных направлений модернизма и авангарда начала XX в.

В связи с этим продуктивным представляется анализ описанных формалистами приемов в текстах авторов, знавших, но не всегда разделявших позиции теоретиков формальной школы. О. Хансен-Леве, О. Ронен, А. Долинин, Я. Левченко показали реализацию «формалистского мировоззрения» и экзистенциальной остраняющей перспективы в прозе скептически отзывавшегося о формалистах В. Набокова. Хансен-Леве подчеркивал, что творчество Набокова демонстрирует «формалистскую поэтику гораздо более объемно и многообразно, <..> чем произведения тех авторов, которые находились в России в личных или методологических контактах с формалистами» ${ }^{2}$.

Мы остановимся на другом интересном примере подобного сближения, рассмотрев реализацию приема «остранения» и принципов «нового зрения» в прозе С. Д. Кржижановского. Он так же, как и Набоков, был современником формалистов, читал работы, но далеко не во всем разделял позиции теоретиков формальной школы.

В «Философеме о театре» Кржижановский упоминает имена В. Шкловского и В. Жирмунского. При этом намеренно ставит их в один ряд с именем А. Потебни, игнорируя неоднозначное отношение к нему формалистов, которое декларировалось уже в ранней работе Шкловского ${ }^{3}$. «По определению Потебни, - писал Кржижановский, $-<\ldots>$ поэзия - это сгущенная мысль; точнее - сгущенная речь. Формальный метод поэтики (Шкловский, Жирмунский и др.) меняют в старом определении лишь слова: „Поэзия - затрудненная форма“"» ${ }^{4}$. Здесь Кржижановский дословно цитирует известную работу Шкловского, который определял «остранение» как «прием затрудненной формыл, увеличивающий трудность и долготу восприятия, <.. >; искусство есть способ пережить деланье вещи, а сделанное в искусстве неважно» (курсив автора. - E. T. $)^{5}$.

В записных тетрадях писателя осталась его скептическая запись: «Формалисты полагают, что вначале был открыт скрипичный футляр, а уж затем стали подумывать, чем его заполнить» (V, 330). Но при ироническом отношении к эпатажности отдельных положений формалистских работ Кржижановскому, думается, были очень созвучны описанные теоретиками формальной школы принципы «остранения», сдвига, «нового зрения», разрушающего привычную сетку причинно-следственных связей.

Умение увидеть вещь с неожиданной точки зрения, «исходя из случайных смещений», разрушающих автоматическое восприятие, присутствует в каждом художественном произведении писателя. Этот «водяной знак» настоящей литературы у Кржижановского вступает во взаимодействие с приемами визуальных искусств (фотографии и кинематографа), применяемых автором в художественных текстах.

Новые медиа интересовали Кржижановского, как и формалистов, прежде всего, с точки зрения богатства ракурсов, открытия новых возможностей для «выведения вещи из автоматизма восприятия». Ю. Тынянов, пересмотрев свое негативное отношению к кинематографу, в статье «Об искусстве кино» писал: «Ракурс стилистически преображает видимый мир. Горизонтальная, чуть наклонная труба фабрики, переход по мосту, заснятый снизу, - ведь это такое же преображение 
вещи в искусстве кино, как целый ассортимент стилистических средств, делающих вещь новой в искусстве слова» ${ }^{6}$.

Как Шкловский и Тынянов, Кржижановский сотрудничал с первыми кинофабриками. Он написал сценарий для «Праздника святого Йоргена» (реж. Протазанов, 1929), «Нового Гулливера» (реж. А. Птушко, 1933-1935). Был у него и рекламный опыт: в 1925 г. он создал «сценарий для Моссельпрома: “Сказка о Мосе, Селе и сыне их Проме"»7. В новеллах писателя можно видеть готовую раскадровку, использование приемов монтажа, «наплыва» камеры («Собиратель щелей», «Проигранный игрок», «Красный снег»). Исследование инертности зрения, впоследствии положенное в основу 25-го кадра, осмысляется Кржижановским с философской точки зрения и порождает «щелиную этику» его героев («Собиратель щелей»).

Интересовался Кржижановский и новыми возможностями, которые дает фотография («Коллекция секунд», «Чужая тема»). С фотографией литературу сближает, по мысли писателя, необходимость найти «свой» объект и «схватить», «застигнуть» его в неповторимом ракурсе (фотографов он называет «ловцы секунд»). Писатель был знаком с М. Наппельбаумом, фотомастерская которого была расположена в том же доме на Тверском бульваре, где он читал свои новеллы на заседаниях «Никитинских субботников». Рецепция фотографии у Кржижановского во многом созвучна поискам А. Родченко, который призывал «снимать обыкновенные, хорошо знакомые предметы с неожиданных точек зрения и в неожиданных положениях <..> чтобы сбросить пелену привычного восприятия вещей» ${ }^{8}$.

Визуальный контекст эпохи изменял призму видения литературного текста‥ В 1917 г., обосновывая термин «остранение», Шкловский делал акцент на необходимости нового видения вещи, употребляя «видение» не только как синоним «восприятия», но прежде всего как «зрение». Полемически заостряя свой тезис, он противопоставлял «видение» «узнаванию», без которого психофизиологический процесс визуального восприятия невозможен. Как считал Шкловский, мешает зоркости привычное отношение к вещи, автоматическое встраивание ее в контекст причинно-следственных связей. «Вещи, воспринятые несколько раз, начинают восприниматься узнаванием: вещь находится перед нами, мы знаем об этом, но ее не видим» ${ }^{10}$.

Трансформация реальности под воздействием нового взгляда становится сюжетом многих произведений Кржижановского (в записных тетрадях писатель оставил фразу «мир - это дочка зрения» $(\mathrm{V}, 355))$. Герой его повести «Странствующее "Странно"» проводит над собой эксперимент, описанный еще картезианцем Николой Мальбраншем (изменение видения, восприятия реальности в зависимости от размера органа зрения $)^{11}$. Выпив волшебной тинктуры, чтобы познать окружающий его мир, он уменьшается до микроскопических размеров, и мир предстает ему абсолютно другим. Он видит бациллы времени, путешествует в конверте к своему сопернику и проникает внутрь его мозга. С многократным уменьшением тела герой приобретает и микроскопическое зрение, видит другую, преображенную реальность. «Когда мне удалось наконец открыть глаза, то первое, что я увидел, были стволы какого-то фантастического безлистного леса, причудливо сплетающего надо мной свои комли. При тусклом брезге дня, еле проникавшем сквозь густую заросль, я разглядел, что стволы деревьев были разных цветов - от черного до светло-рыжего. В некоторых местах их толща была сквозиста, так что сквозь одни стволы можно было смутно разглядеть контуры других» (I, 286). Таким предстает перед героем обычный ковер.

Об ускользающем понятии реальности писал современник Кржижановского Евгений Замятин: «Как будто так реально и бесспорно: ваша рука. Вы видите гладкую, розовую кожу, покрытую легчайшим пушком $<\ldots>$ И вот - кусочек этой кожи, освященный (так. $-E$. T.) жестокой иронией микроскопа: канавы, ямы, межи; толстые стебли неведомых растений - некогда волосы; огромная серая глыба земли - или метеорит, свалившийся с бесконечно далекого неба - потолка, - то, что недавно еще было пылинкой; целый фантастический мир, быть может, равнина где-нибудь на Марсе. И все же это - ваша рука. И кто скажет, что “реальная" - эта вот, привычная, гладкая, видимая все Фомам, а не та - фантастическая равнина на Mapce?» ${ }^{12}$. Позднее близкую мысль выразил и Владимир Набоков: «Реальность - очень субъективная штука $<\ldots>$. Лилия более реальна для натуралиста, чем для обычного человека, но она еще более реальна для ботаника $<\ldots>$ Вы можете $<\ldots>$ подбираться к реальности все ближе и ближе; но вы никогда не подойдете достаточно близко, так как реальность - бесконечная последовательность шагов, уровней восприятия, ложных лиц, а потому она неутолима, недостижима...» ${ }^{13}$

В ряде случаев «остраненное видение» у Кржижановского доводится до предела-возникает образ глаза, отделенного от субъекта («Грайи», «Четки», «Страна нетов»). В новелле «Грайи» писатель создает свое продолжение античного мифа. По его версии, глаз грайи, выхваченный Персеем, упал не в болото, а в землю. И на сто первую весну пророс. Писатель обыгрывает термин «глазное яблоко», строя дальнейший образ на буквальном прочтении метафоры. «Сначала от глазного корня пополз белый и рыхлый осевидный отросток тоненького, в волосок, нервного волоконца. $<\ldots>$ Из зрачка протолкнулся вверх мутный стеклистый побег» (I, 152). А осенью «на диковинном деревце, повиснув на белых осевидных фибриллах, прокруглились свесившиеся зрачками вниз, маленькие, понемногу полнящиеся и наливающиеся нервным соком стеклисто-белые глазные 


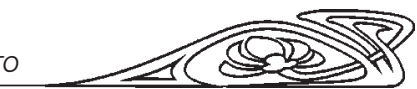

яблоки» (I, 153). Это описание проросшего глаза напоминает серию литографий Одилона Редона, где глаз растет, подобно гигантскому цветку, или, как странный шар, поднимается в бесконечность.

В новеллах «Якоби и “якобы”», «В зрачке», «Страна нетов», «Четки», повести «Возвращение Мюнхгаузена» человеческий глаз уподобляется Вселенной: «...был момент, когда испуганным умам показалось, что вся эта - такая пестрая и огромная (на первый взгляд!), сферическая, со сплюснутостью полюсов, земля и крошечный сферический хрусталик человеческого глаза одно и то же» (I, 272). Не раз встречающийся у Кржижановского мотив отъединения глаза от своего субъекта вызывает визуальные ассоциации: с картинами «Кривое зеркало» Рене Магритта, «Глаз» Мориса Эшера, с инсталляцией Ман Рея «Object to be Destroyed» (1923), представляющей собой гигантский метроном, к стрелке которого прикреплена во много раз увеличенная фотография женского глаза.

Необходимо отметить, что в произведениях авангарда подобный образ глаза, отъединенного от субъекта, был связан не только с абсолютизацией зрения, но и фиксировал диссонанс между непреложной истинностью зрения, его связью с духовной деятельностью, с одной стороны, и осознанием его физиологической природы, с другой. Если для философов античности, художников Ренессанса зрение служило философской метафорой познания реальности, то уже в XIX в. адекватность зрительного опыта все чаще ставится под сомнение. Е. Бобринская, анализируя истоки «нового зрения» русского авангарда, писала: «Исследования последовательных образов на сетчатке, изучение инерции зрения и различных трансформаций зрительных образов во времени, а также детальные исследования физической поверхности глаза (в работах Мюллера, Пуркинье и Гельмгольца) серьезно меняют представления о совершенности и истинности “оптического аппарата" - глаза, и эта утрата безусловной достоверности зрения оказывается одним из слагаемых в новой релятивистской картине мира» ${ }^{14}$.

Успехи в развитии оптики и физиологии позволили детально изучить устройство глаза как органа зрения, а изобретение фотографии и кинематографа создало такие «оптические протезы», которые могли осуществлять механическое наблюдение за реальностью в отрыве от субъек$\mathrm{Ta}^{15}$. Границы человеческого зрения необычайно расширяются: «Глаз, вооруженный оптическим инструментарием, был способен проникать в невидимые уровни реальности $<\ldots>$ Отныне глаз рассматривался не только как точное измерительное устройство, но и как чувствительный прибор, способный видеть и ощущать жизнь в изменчивости и бесконечной визуальной регрессии» ${ }^{16}$.

Кржижановский постоянно интересовался открытиями оптики, квантовой механики, физиологии зрения, и в его новеллах научные данные разрушают обыденное представление о реальности, становятся генератором фантастических событий («Собиратель щелей»), связываются с экзистенциальными проблемами. Носителями «остраненного видения» становятся и «оптические протезы» - очки, пенсне - тоже герои произведений писателя («Автобиография трупа», «Глазунья в пенснэ»). Цветан Тодоров называл очки своеобразным «символом непрямого, искаженного взгляда», «квинтэссенцией взгляда» в литературе и показал их сюжетообразующую роль в фантастической литературе ${ }^{17}$.

Образ очков (с разными функциональными нагрузками) - один из частотных в литературе 20-30-х гг. У Кржижановского он мотивирован и автобиографически. В. Г. Перельмутер писал: «Сам Кржижановский, смолоду вынужденный пользоваться “стеклистыми придатками”, судя по фотографиям, носил именно пенснэ. Мотив-оппозиция < ..> “близорукости" и “стекол" < ..> впервые возникает в новелле "Чуть-чути" $(1922)<\ldots>$ и с тех пор становится одним из сквозных в символико-метафорической системе Кржижановского, не только в прозе, но и в размышлениях о литературе и театре» ${ }^{18}$. Очки и пенсне появляются в первом подготовленном к печати сборнике писателя, присутствуют в его записных тетрадях, эссе, являются центральным образом его последнего рассказа. Изобретение «оптических протезов» - очков, линз для микроскопа и телескопа - вооружают глаз, позволяют увидеть незримое. Но одновременно они ставят под сомнение совершенство естественного зрения. Происходит «делокализация зрения», отрыв зрения от тела.

Заглавный образ последней новеллы Кржижановского «Глазунья в пенснэ» рождается благодаря бытовой нелепице: падению пенсне в сковородку с яичницей. Писатель ведет игру на сходстве внутренней формы слов «глазунья» и «глаз», обусловленном их этимологическим родством. Возникает и ассоциация с трактатом Леонардо да Винчи «О строении человека и других животных», где автор, описывая физическое строение глаза, давал советы грамотного препарирования: «При анатомировании глаза, для того чтобы хорошо разглядеть внутри, не проливая его влаги, надобно положить глаз в яичный белок и прокипятить и укрепить, разрезая яйцо и глаз поперек, дабы средняя часть снизу не пролилась» ${ }^{19}$. Далее случайное соединение предметов (ср. с манифестами сюрреализма) приводит к отчуждению привычного объекта - «простого стеклянного двуглазья с глупым именем: пенснэ» (IV, 169). «Два стеклянных эллипса прижались к огромным, выпученным, лишенным зрачков желтым глазам и смотрели на меня снизу вверх» (IV, 167).

«Остранение» привычного предмета не только рождает новый образ, но и генерирует «странный» фантастический сюжет новеллы. Увиденное по-новому днем, пенсне оживает но- 
чью: «Пенснэ приподнялось, привстав на своих коротких металлических ножках. Оно вышагнуло из футляра, волоча два огромных стеклянных глаза, и подвинулось к самому краю стола. В его двояковогнутых глазах, как всегда, мерцали тусклые лунные блики. Оно смотрело на меня чрезвычайно внимательно, изредка переступая с одной куцей металлической ножки на другую» (IV, 168). Пенсне из посредника между глазом и миром превращается в самостоятельный субъект зрения. Признавая свое несовершенство («Телосложение у меня - надо признать - нескладное. Эти запавшие огромные стеклянные глаза на рахитических ножках» (IV, 170)), принадлежность человеку и вынужденную зависимость от него («И жить я не могу само по себе. Приходится ютиться при чужих глазах. Присасываться к чужому видению» $(\mathrm{IV}, 170))$, пенсне, тем не менее, утверждает, что обладает зрением более совершенным, чем его хозяин. «Но убежден ли ты, что я делюсь всем, что вижу, всем, что вбираю вот в эти стеклянные чечевицы, с твоими глазами? А может быть, я отдаю им лишь то, что считаю нужным отдать, а остальное удерживаю для себя? О, если б мне было можно рассказать о том, что ты не увидел: через меня! О тех образах, которые скользнули по моим стеклам, отразились в них, как в прозрачных зеркалах, но так и не вошли в твою психику. О том, что ты видел, но не увидел» (IV, 169). Возникает тема отчужденного, «остраненного» от человека взгляда. «Зрительный протез» - пенсне - не столько корректирует несовершенное физическое зрение героя, сколько отражает свет, похищает визуальные образы.

Здесь Кржижановский развивает прием, использованный им ранее в новелле «Автобиография трупа», датированной 1927 г. $^{20}$ Там падение пенсне становится причиной разрыва героя с любимой девушкой: «Губы наши приблизились друг к другу - и в этот-то миг и приключилась нелепица: неловким движением я задел стеклами о стекла; сцепившись машинками, они скользнули вниз и с тонким, острым звоном упали на ковер. Я нагнулся: поднять. В руках у меня было два странных стеклянных существа, крепко сцепившихся своими металлическими кривыми ножками в одно отвратительное четырехглазое существо. Дрожащие блики, прыгая со стекла на стекло, сладострастно вибрировали внутри овалов. Я рванул их прочь друг от друга: с тонким звоном спарившиеся стекла расцепились. < .. > Через минуту я спускался вниз по лестнице. И у меня было ощущение, как если бы я в темноте наткнулся на труп» (II,514).

Пенсне предстает перед героем как увиденное впервые. Нелепое соединение двух «странных стеклянных существ» рождает новый образ «одно отвратительное четырехглазое существо». На долю секунды оно оживает в сознании героя. Здесь писателем используется визуальное сходство овалов пенсне с глазами и омонимичность названия крепления пенсне - «ножки»: «... я разжал ему (пенсне. $-E$. T.) металлические ножки и, держа на уровне лица, стал внимательно всматриваться в его огромные овально-раскосые двояковдавленные глаза. И не знаю: был ли то простой солнечный рефлекс или иное что, но в глазах придатка искрился острый и радостный блеск» (II, 529).

Нелепый случай принимается героем как «предметный урок, преподанный < ..> “стеклистым придатком”» (II, 516), и наделяется символическим значением. Вместо гармонии, объединяющей любящих молодых людей, образуется несуразное уродливое существо, в овалах которого «сладострастно вибрировали» «дрожащие блики».

В «Автобиографии трупа» пенсне, как и в последней новелле писателя, способно деформировать зрение, «ломать не только лучи». Падение пенсне становится поворотным моментом в жизни героя. В него вселился «стеклисто-прозрачный холод» (II, 515), он ощутил обреченность на одиночество, прекратил «все эти опыты с дружбой, < . .> порыванья дать или взять любовь», отказался от «всяких попыток войти в свое “вне"» (II, 516). Самосознание, отношения с миром ассоциируются у героя с визуальным образом: «И целые дни от сумерек до сумерек я думал о себе как о д в о я к о в о г н у т о м с у щ е с т в е, которому ни вовне, ни вовнутрь, ни из себя, ни в себя: и то и это - равно запретны. Вне досяганий» (II, 515).

Принципиально субъективное видение становится причиной отчуждения, экзистенциального одиночества человека: «меж “я” и “мы”: “ямы”» (II, 522). В «Автобиографии трупа» герою вспоминается сочинение Гербенштейна, германского дипломата, который приводит толкование происхождения названия Россия «от арамейского слова Ressia или Resessaia, что означает: разбрызганная по каплям» (II, 521). «Именно среди нас, из поколения последышей, возникает философема о чужом "я": не мое "я" мыслится чужим и чужеродным, непревратимым в “ты”. Люди-брызги не знают ни русла, ни течения» (II, 522).

Связь в «Автобиографии трупа» проблемы бытия «я» и «другого», «попыток войти в свое “вне”» с визуальностью соотносятся с центральными положениями создававшейся в это время (в первой половине 1920-х гг. ${ }^{21}$ ) работы М. Бахтина «Автор и герой в эстетической деятельности». В оставшейся незавершенной работе, опубликованной уже после смерти ученого 22 , Бахтин пишет об «абсолютной эстетической нужде человека в другом, в видящей, помнящей, собирающей и объединяющей активности другого, которая одна может создать его внешне законченную личность», ибо «только в другом человеке дано мне живое, эстетически (и этически) убедительное переживание человеческой конечности, эмпирической ограниченной предметности» ${ }^{23}$.

Бахтин подчеркивает, что именно «действия созерцания», «избыток видения» другого форми- 
рует самосознание личности: «...мы постоянно и напряженно подстерегаем, ловим отражения нашей жизни в плане сознания других людей, и отдельных ее моментов и даже целого жизни» ${ }^{24}$. Для нас важно, что эстетическое и философское понимание необходимости «другого» сознания для формирования «я» личности связывается Бахтиным с «действиями созерцания, вытекающими из избытка внешнего и внутреннего видения другого человека...»: «...всегда наличный по отношению ко всякому другому человеку избыток моего видения» восполняет личность «другого». Исследователь подчеркивает визуальную ценность вненаходимости: «Ведь в каждый данный момент <..> я всегда буду видеть и знать нечто, чего сам он со своего места вне и против меня видеть не может: части тела, не доступные его собственному взору, - голова и лицо и его выражение - мир за его спиной, целый ряд предметов и отношений, которые при том или ином взаимоотношении нашем доступны мне и недоступны ему» ${ }^{25}$.

Ключевым и наиболее цитируемым в современных исследованиях стал тезис Бахтина об «избытке видения автора по отношению к каждому герою» как необходимом условии эстетической завершенности произведения ${ }^{26}$.

Для героя Кржижановского «любящее сознание другого» (Бахтин) закрыто. Герой хочет забыть «эксперименты с чужим “я”» (II, 516). Он прекращает «попытки проникнуть в мир, начинающийся по ту сторону < .. > двояковогнутых овалов» (II, 516), пытается создать свой «сплющенный мирок, в котором все было бы здесь, - мирок, который можно было бы защелкнуть на ключ внутри своей комнаты» (II, 516). Этот сплющенный мирок визуально ассоциируется у героя с «двояковогнутым» пространством между двумя зацепившимися друг за друга пенсне.

Занимаясь «филологией “я”», герой замечает: «...у "я" изменчивый корень, но всегда короткая фонема $<$.. > Можно предполагать процесс укорочения, так называемое "стяжение"» (II, 516) 27 . Это «стяжение» происходит и с личностью, индивидуальным миром героя. Он предпочитает «нелепо огромному» пространству «однообразных верст земных полей» «узкие книжные поля» (II, 516). «Укорочение» пространства связано с физическими особенностями зрения автора рукописи. «Давно ношу поверх зрачков стекла. Приходится из года в год повышать диоптрии: сейчас у меня 8,5. Это значит 55 \% солнца для меня нет. Стоит втолкнуть мои двояковогнутые овалы в футляр - и пространство, будто и его бросили в темный и тесный футляр, вдруг укорачивается и мутнеет. Вокруг глаз серые ползущие пятна, муть и длинные нити круглых прозрачных точек. Иногда, когда протираю замшей мои чуть пропылившиеся стекла, курьезное чувство: а вдруг с пылинами, осевшими на их стеклистые вгибы, и все пространство - было и нет: как налипь» (II,
513) Это «минус»-пространство (В. Н. Топоров), многократно и разнообразно «разыграно» в текстах Кржижановского.

Возможность постижения реальности, другого бытия - одна из основных проблем прозы Кржижановского. И центральная роль в процессе восприятии мира отводится писателем зрению. Но само строение глаза и физиология зрения устроены на двойном отражении, двойном переворачивании объекта. Насколько адекватен полученный образ реальности, этот вопрос постоянно ставит Кржижановский. В повести «Клуб убийц букв» герой убежден: «Помоему, тут все довольно просто: каждое трехмерное существо дважды удвояет себя, отражаясь вовне и вовнутрь. Оба отражения неверны: холодное и плоское подобие, возвращаемое нам обыкновенно стеклянным зеркалом, неверно уже потому, что менее чем трехмерно, распластанно; другое отражение лица, отбрасываемое им внутрь, втекающее по центростремительным нервам в мозг, состоящее из сложного комплекса самоощущений, тоже неверно, потому что более чем трехмерно» (II, 24).

«Остранение» было обусловлено и жизненной позицией автора, «вытесненного» из официальной литературы. В 1920-х гг. Кржижановский пытался активно участвовать в литературной и культурной жизни столицы: преподавал в Экстемасе (Экспериментальных театральных мастерских при Камерном театре) и, по предложению Таирова, написал пьесу «Человек, который был Четвергом» («по схеме Честертона»), шедшую в театре в 1923-1924 гг; был контрольным редактором в издательстве «Энциклопедия» и в журнале «В бой за технику»; читал свои произведения в Третьей студии МХT, на заседаниях Вольфилы, в Таировском театре, на квартирах у друзей, принимал участие в «Никитинских субботниках». Тем не менее ни один из подготовленных им сборников рассказов, ни одна повесть не были изданы при жизни Крижижановского ${ }^{28}$. Вокруг писателя одни «возвры», как говорит один из его героев: «В углышках всех моих рукописей они поставили: № и “Возвр"» (II, 590).

Вынужденный «взгляд со стороны» подмечал всю абсурдную логику, парадоксальность советской действительности: «Не пойму - Издво: не то издательство, не то издевательство» $(\mathrm{V}$, $322)$; «Литература - борьба властителей дум с блюстителями дум» (II, 192), «Всем перьям у нас дано выбирать: пост или пост - одним - бессменно на посту; другим - литературное постничество» (II, 193). Расхождение с общепринятым мнением было выражено у Кржижановского зрительной метафорой - «мировоззрение не моих диоптрий» $(\mathrm{V}, 406)$. Умение видеть мир неповторимым - «остранение» - в 1930-е гг. вело к «отстранению»: от литературы, читателя, признания, что отразилось и на судьбах теоретиков формальной школы. 


\section{Примечания}

1 См.: Шкловский В. Искусство как прием // Шкловский В. Гамбургский счет. М., 1990. С. 63-66. Об универсальности описанного Шкловским приема см.: Ханзен-Леве О. Русский формализм. Методологическая реконструкция развития на основе принципа остранения. М., 2001. С. 12-36 ; Гинзбург К. Остранение : Предыстория одного литературного приема // Новое литературное обозрение. 2006. № 80.

2 Ханзен-Леве О. Русский формализм... С. 558.

3 Шкловский В. Потебня // Поэтика : сб. Пг., 1919.

4 Кржижановский С. Философема о театре // Кржижановский С. Собр. соч. : в 6 т. Т. 4. СПб., 2006. С. 77. Далее тексты С. Кржижановского цитируются по : Кржижановский С. Собр. соч. : в 6 т. СПб., 2001-2013 тома и страницы с указанием в скобках.

5 Шкловский В. Искусство как прием. С. 63.

6 Тынянов Ю. Поэтика. История литературы. Кино. М., 1977. С. 330.

7 Кржижановский С. Письмо А. Бовшек 8. 08. 1925 // РГАЛИ. Ф. 2280. Оп. 1. Ед. хр. 77. Л. 16 (об.).

8 Родченко А. Пути современной фотографии // Родченко А. Статьи. Воспоминания. Автобиографические записки. Письма. М., 1982. С. 107.

9 См.: Трубеиякова Е. «Новое зрение» : визуальные коды русского формализма // Изв. Сарат. ун-та. Нов. сер. Сер. Филология. Журналистика. 2012. Т. 12, вып. 3. С. 39-43.

10 Шкловский В. Искусство как прием. С. 64.

11 Никола Мальбранш писал о том, что одинаковое физиологическое строение глаза не отменяет различия видения одного и того же предмета разными людьми: «... нельзя утверждать, что найдутся в мире два человека, которым предметы казались бы совершенно одинаковой величины или состоящими из одинаковых частей, так как нельзя утверждать, что глаза их совершенно одинаковы» (Мальбранш Н. Разыскания истины. СПб., 1999. С. 74-75). См. анализ этого эпизода новеллы Кржижановского в философском и историконаучном контексте: Ямпольский М. О близком : Очерки немиметического зрения. М., 2001. С. 27-30.

12 Замятин Е. О синтетизме // Замятин Е. Избранные произведения. М., 1990. С. 413.

13 Набоков о Набокове и прочем : Интервью, рецензии, эссе / ред.-сост. Н. Г. Мельнихор. М., 2002. С. 118.

14 Бобринская И. Новое зрение // Бобринская И. Русский авангард : границы искусства. М., 2006. С. 233.

15 См.: Верильо П. Машина зрения. СПб., 2004.

16 Бобринская И. Новое зрение. С. 262.
17 См.: Тодоров Ц. Введение в фантастическую литератуpy. М., 1997. С. 164-180.

18 Перельмутер В. Комментарии // Кржижановский С. Собр. соч. : в 6 т. Т. 5. СПб., 2010. С. 546.

19 Леонардо да Винчи. О строении человека и других животных // Леонардо да Винчи. Суждения о науке и искусстве. СПб., 2006. С. 169-170.

20 Из переписки С. Д. Кржижановского с А. Г. Бовшек видно, что новелла была завершена уже в 1925 г. и принята к публикации журналом «Россия» (письмо к А. Г. Бовшек 17 июля 1925 г.). Как считает В. Г. Перельмутер, несмотря на то что публикация так и не состоялась, автор в дальнейшем не возвращался к переработке новеллы (Перельмутер В. Комментарии // Кржижановский С. Собр. соч. : в 5 т. Т. 2. СПб., 2001. С. 683-685).

21 Аверинцев С. Комментарии // Бахтин М. Работы 20-х годов. Киев, 1994. С. 326.

22 В 1986 г. работа была опубликована сразу в трех изданиях : Бахтин М. Эстетика словесного творчества. М., 1986 ; Бахтин М. Литературно-критические статьи. М., 1986 ; Философия и социология науки и техники : ежегодник. М., 1986.

23 Бахтин М. Работы 20-х годов. Киев, 1994. С. 116.

24 Там же. С. 99.

25 Там же. С. 105.

26 Там же. С. 98.

27 «Филология “я”», которой занимается герой Кржижановского, включается в круг разрабатываемой в 1920-е гг. Бубером, Хайдеггером, Марселем, Бахтиным, Кассирером проблемы «Я» и «другого», на что указал В. Н. Топоров (См.: Топоров В. «Минус»-пространство Сигизмунда Кржижановского // Топоров В. Миф. Ритуал. Символ. Образ : Исследования в области мифопоэтического. М., 1995. С. 574).

28 Было опубликовано только несколько рассказов в журналах: в киевском альманахе «Зори», еженедельнике «Неделя искусства, литературы и театра», журнале имажинистов «Гостиница для путешествующих в прекрасном». Единственный опубликованный очерк «Штемпель: Москва» вышел в журнале «Россия» (1925, № 5). В 1931 г. вышла небольшая литературоведческая брошюра «Поэтика заглавий» (изд-во «Никитинские субботники»). О художественном осмыслении собственного вынужденного молчания см: Трубецкова $E$. «Авторы - вторы - воры»: судьба писателя в прозе С. Кржижановского // Творческая биография писателя в контексте эпохи. Фединские чтения. Вып. 4 / под ред. Л. Е. Герасимовой ; сост. И. Э. Кабанова, И. В. Ткачева. Саратов, 2010. С. 181-189. 